\title{
Element signature analysis: its validation as a tool for geographic authentication of the origin of dried beef and poultry meat
}

\author{
Bettina M. Franke • Max Haldimann • \\ Gérard Gremaud · Jacques-Olivier Bosset • \\ Ruedi Hadorn · Michael Kreuzer
}

Received: 18 July 2007 / Revised: 26 September 2007 / Accepted: 8 October 2007 / Published online: 21 October 2007

(C) Springer-Verlag 2007

\begin{abstract}
Element concentrations of 56 poultry meat and 53 dried beef samples were determined and statistically analyzed using analysis of variance and linear discriminant analysis (LDA) to identify the single or combination of elements with the highest potential to determine the geographic origin. In order to validate the applicability of this technique, the results were additionally combined with data from an earlier assessment including 25 poultry meat and 23 dried beef samples. Validation was performed by estimating the origin of the first samples based on the data of the second, larger, dataset. Elements significantly discriminating among countries were $\mathrm{As}, \mathrm{Na}, \mathrm{Rb}, \mathrm{Se}, \mathrm{Sr}$, and $\mathrm{Tl}$ for poultry meat and $\mathrm{As}, \mathrm{B}, \mathrm{Ba}, \mathrm{Ca}, \mathrm{Cd}, \mathrm{Cu}, \mathrm{Dy}, \mathrm{Er}, \mathrm{Fe}$, $\mathrm{Li}, \mathrm{Mn}, \mathrm{Pd}, \mathrm{Rb}, \mathrm{Se}, \mathrm{Sr}, \mathrm{Te}, \mathrm{Tl}, \mathrm{U}$, and $\mathrm{V}$ for dried beef out of about 50 elements each. The LDA gave mean correct classification rates of 77 and $79 \%$ for poultry meat and dried beef, respectively. Validation allowed identifying some, but not all, origins. For a higher discriminative power, this method should be combined with other ways of authentication.
\end{abstract}

Keywords Beef · Broiler · Meat · Trace elements . Authentication · Traceability

B. M. Franke $\cdot$ M. Kreuzer $(\bowtie)$

Institute of Animal Science, ETH Zurich,

Universitätstrasse 2, 8092 Zurich, Switzerland

e-mail: michael.kreuzer@inw.agrl.ethz.ch

M. Haldimann · G. Gremaud

Swiss Federal Office of Public Health,

3003 Berne-Liebefeld, Switzerland

J.-O. Bosset · R. Hadorn

Agroscope Liebefeld-Posieux Research Station ALP,

3003 Berne-Liebefeld, Switzerland

\section{Introduction}

During the past years, several studies on determining the geographic origin of meat were undertaken. Among others, trace elements were stated as very promising for this purpose [1-5]. First indications for the suitability of this approach in authentication of poultry meat and dried beef were presented earlier [6]. Elements useful in determining the geographic origin of foods can be classified into different types of indicators. Primary indicators are directly connected to the geographic origin because the geological profile is unique or certain elements appear in some regions in characteristic concentrations e.g. as a result of pollution. Secondary indicators are not directly connected to the geographic origin such as features caused by feeding the animals and those found in processed meat introduced for instance by deboning, cutting, curing, seasoning, smoking or other processing steps. Animals kept in regions with distinct characteristics could reflect these specific element levels because of intake with water and locally grown feeds; thus allowing their assignment to site of origin. Examples for such natural characteristic elements and element profiles include $\mathrm{As}, \mathrm{Cd}, \mathrm{K}, \mathrm{Mo}, \mathrm{Rb}, \mathrm{Se}$, and Tl. Arsenic is prevalent in soil and ground water of distinct regions of India, Thailand, and Bangladesh [7-9]. In poultry meat, it had been possible to differ between Thai origin and origin from Switzerland, France, Germany, Hungary, and Brazil using the As content [6]. Uraniferous black shale was described to be rich in $\mathrm{Cd}, \mathrm{Mo}$, and $\mathrm{Se}$ [10]. In meat, $\mathrm{Cd}$ levels could be used to differ between various countries [11], and in Slovenian poultry, kidneys from different geographic regions [12] could be determined by their $\mathrm{Cd}$ contents too. Selenium is known to be much higher in American soil than in European soil. This was found to be reflected in meat [13] and turned out to be useful to distinguish between eggs originating from several 
regions in Chile [14]; thus making Se a good indicator to verify geographic origin [2]. Potassium levels are typically lower in soil and grass of higher altitudes [15], whereas $\mathrm{Rb}$ contents again vary depending on the geologic underground [1]. Thallium ( $\mathrm{Tl})$ is enriched, for example, in some areas of France [16] and China [17], which likely facilitates the differentiation between French poultry from that of Brazil, Germany, Hungary, Switzerland, and Thailand [6]. Specific element profiles, resulting from anthropogenic influences, especially pollution, include $\mathrm{As}, \mathrm{Cd}, \mathrm{Hg}, \mathrm{Pb}, \mathrm{Tl}$, and $\mathrm{Zn}$ [e.g. 18-20]. When enrichments of such elements are found, a direct link to their geographic origin might be drawn too.

Limitations are given by accumulation rates. The comparison of sheep housed in areas polluted with $\mathrm{Cd}, \mathrm{Pb}$, and $\mathrm{Zn}$ with sheep from unpolluted areas [21] showed that muscle tissue does not accumulate every element. This means that a specific element profile of a certain area is not necessarily reflected in the meat of animals living there. Useful elements to determine the geographic origin are especially those being not essential to animals and/or being toxic at higher levels, as their use in mineral supplementation is unlikely or harmful. This at least partially excludes the usefulness of $\mathrm{Ca}, \mathrm{Cl}, \mathrm{Cu}, \mathrm{I}, \mathrm{Na}, \mathrm{Mg}, \mathrm{Mo}, \mathrm{P}, \mathrm{S}, \mathrm{Se}$, and $\mathrm{Zn}$ in poultry meat $[22,23]$, and $\mathrm{Ca}, \mathrm{Co}, \mathrm{Cu}, \mathrm{I}, \mathrm{Mg}, \mathrm{Mn}, \mathrm{Na}, \mathrm{P}, \mathrm{S}$, and $\mathrm{Zn}$ in beef [24, 25]. Even if it is possible to clearly distinguish origins by such elements, they can be changed easily with the consequence of an altered profile. This was shown for instance in Finland where Se fertilization over decades increased Se in various foods [26], including beef (from 0.04 to $0.34 \mathrm{mg} \mathrm{Se} / \mathrm{kg}$ from 1975 to 2004), and by Hintze et al. [27] for beef, also. Indirect contamination may occur e.g. by phosphate supplements containing elevated levels of $\mathrm{Cd}$ [28] or As present in diets containing fish meal [8]. Other indicators, giving good links to the place of processing, are limited in their value as the process itself can be easily adapted, once such features are known. This illustrates that for the discrimination of origins from various countries, characteristic multi-element signatures might be more useful than single elements.

In a preliminary study, a large set of elements possibly useful for the determination of the geographic origin had been identified, and the usefulness of element profiles had been demonstrated [6]. The aim of the present study was to validate the conclusions drawn in the preliminary assessment. In detail, it should be determined (1) if in a second, much larger, sample set the same individual elements turn out to be useful in geographic discrimination, (2) if a multielement signature is indicative again, and (3) whether data obtained at different time periods fit sufficiently together. The latter would allow estimates on geographic authentication based on assessments performed earlier and also to combine data obtained successively.

\section{Materials and methods}

Sample selection and preparation

Frozen samples of poultry meat (five breast fillets without skin each) were obtained from five different countries: Brazil ( $n=10$ independent samples), France $(n=11)$, Germany $(n=12)$, Hungary $(n=10)$, and Switzerland $(n=13)$. All samples were from conventionally housed broilers. The authenticity of all samples had been certified with valid custom documents which also specified slaughter place and date. Samples were kept frozen at $-25{ }^{\circ} \mathrm{C}$. Sample material for analyses $(0.8 \mathrm{~g})$ was taken from the middle of one randomly chosen breast fillet using a ceramic knife in order to prevent contamination with metals.

Dried beef was obtained from five different countries of origin of the raw beef and six different sites of processing. The dried beef produced in Switzerland was directly collected at the site of production (Swiss Canton Valais: $n=12$, Swiss raw beef; Swiss Canton Grisons: $n=24$, thereof Swiss raw beef: $n=12$, Brazilian raw beef: $n=12$ ). The non-Swiss samples were purchased directly from producers in Austria ( $n=4$, using raw Brazilian beef), Canada ( $n=6$, raw Canadian beef), USA ( $n=3$, raw US beef) and Australia ( $n=4$, raw Australian beef). All samples had been produced by a sequence of pressing and drying after curing, using either $M$. biceps femoris or M. semitendinosus. Dried beef sample sizes were 0.4 to $0.8 \mathrm{~kg}$, and samples were shrink-wrapped and stored in a cooling room at $2.5{ }^{\circ} \mathrm{C}$. Portions for analyses $(0.4 \mathrm{~g})$ were taken from the center of the whole piece of dried beef again by using a ceramic knife.

\section{Element analysis}

Sample preparation and treatment for the determination of the concentration of various elements and isotopes were done as described in detail before [6], whereas the mineralization procedure was different from that. Now $0.2 \mathrm{~g}$ of reference material (bovine muscles, BCR-CRM 184, Community Bureau of Reference, Geel, Belgium; NISTRM 8414 National Institute of Standards \& Technology, Gaithersburg, USA) and $0.4 \mathrm{~g}$ of dried beef and $0.8 \mathrm{~g}$ of poultry meat, respectively, were placed into a Quartz tube together with $3 \mathrm{ml}$ nitric acid $(650 \mathrm{~g} / \mathrm{kg}$, suprapure, Merck, Darmstadt, Germany). Digestion was carried out using a new microwave oven (ultraCLAVE III, MLS GmbH, Leutkirch, Germany). The temperature and pressure were increased to $255{ }^{\circ} \mathrm{C}$ and 135 bar within 30 min and maintained for another $45 \mathrm{~min}$. A maximum of 40 samples could be digested in the same run, including both of the certified reference samples. The digested solution was diluted to approximately $12 \mathrm{~g}$ with ultra pure water $(>18 \mathrm{M} \Omega$ ) and 
stored in plastic tubes $(15 \mathrm{ml}$, PP, Sarstedt, Sevelen, $\mathrm{CH}$, USA) until analysis was performed, as already described in [6]. The use of the new microwave oven had been resulting in a more complete digestion. Additionally, the software of the ICP-MS was updated; in the meantime a new functionality for mass resolutions 4,000 and 10,000 was mainly entailed. Additionally some instrumental parameters had to be adapted. The radio frequency-power was now $1,320 \mathrm{~W}$. A new nebulizer, made of perfluoroalkoxy polymer (PFA) ( $\mu$ Flow-100; Elemental Scientific, Omaha, NE, USA) was operated at an argon flow rate of $0.84 \mathrm{l} / \mathrm{min}$. The auxiliary argon flow rate was $0.8 \mathrm{l} / \mathrm{min}$, and the plasma flow rate $16 \mathrm{l} /$ min. The nebulizer was fitted to a Scott double-bypass spray chamber using a PFA end cap (Elemental Scientific). Additional argon gas $(0.28 \mathrm{l} / \mathrm{min})$ was introduced to the sample aerosol through a second port on the end cap. This configuration allowed independent optimization of the nebulizer and injection flow rates, thereby improving aerosol formation and reducing deposition of drops that re-aspirated from the nebulizer tip. This sample introduction system reduced both blank levels and noise associated with aerosol formation.

\section{Statistical analysis}

All statistical analyses were performed with Systat (version 11, Systat Software Inc, Richmond, CA, USA). Before statistical evaluation was performed, elements with concentrations below their detection limits were eliminated. In cases where several isotopes of one element had been determined, only the most abundant isotope was used for statistical analysis after confirming that differences between contents of isotopes were consistent across the samples. Significance of meat origin was determined by analysis of variance (ANOVA). For beef, groups were defined depending on both raw meat origin and place of processing. This resulted in two groups with raw Brazilian beef (processed in Austria and Switzerland) and three groups of Swiss dried beef (Swiss raw meat but processed in the cantons of Valais and Grisons, and Brazilian raw beef processed in Grisons). Bonferroni-adjusted pairwise comparisons among means were used in order to discriminate among origins in case the factor origin had been significant in ANOVA. As a second way of data analysis, the datasets were analyzed using linear discriminant analysis (LDA) with stepwise backward elimination (probability to enter/to remove: 0.15). Additionally, data (including all isotopes, thus to estimate the ones most helpful to discriminate the origins) of the present sampling were combined with data of the previously carried out analysis [6] comprising another 22 poultry meat and 21 dried beef samples from the same countries of origin as in the present assessment. The reference material, analyzed in both studies, was compared using a Wilcoxon-
Mann-Whitney test (probability $>0.01$ ) to identify elements differing in concentrations in the two studies. These elements, and those below detection limit in at least one of the two analyses, were excluded from further statistical analysis. Then LDA with stepwise backward elimination was performed building a classification matrix (jackknife cross-validation). Finally, the origin of the samples of the preliminary dataset [6] was predicted using the discriminant model based on data of the present sampling (validation).

\section{Results and discussion}

Discrimination of poultry meat origins by individual elements and element signature

In poultry meat, ${ }^{9} \mathrm{Be},{ }^{52} \mathrm{Cr},{ }^{104} \mathrm{Pd},{ }^{109} \mathrm{Ag},{ }^{113} \mathrm{Cd},{ }^{128} \mathrm{Te},{ }^{137} \mathrm{Ba}$, ${ }^{151} \mathrm{Eu},{ }^{153} \mathrm{Eu},{ }^{159} \mathrm{~Tb},{ }^{163} \mathrm{Dy},{ }^{167} \mathrm{Er},{ }^{169} \mathrm{Tm},{ }^{175} \mathrm{Lu}$, and ${ }^{232} \mathrm{Th}$ remained below the detection limit. Out of the remaining 50 elements analyzed, the concentrations of $\mathrm{As}, \mathrm{Na}, \mathrm{Rb}, \mathrm{Se}$, $\mathrm{Sr}$, and $\mathrm{Tl}$ were different $(p<0.05)$ among countries (Table 1). $\mathrm{Na}, \mathrm{Rb}$, and $\mathrm{Tl}$ were discovered earlier to be useful to distinguish the geographic origin of poultry meat [6]. Although in the first study there were no significant differences in As content between Hungary, Germany, and France, Hungarian samples showed trend towards higher levels than German and French poultry meat; differences found to be significant in the present dataset. In the earlier study, Na had been useful to differ between Swiss and Thai poultry meat, and now Swiss poultry meat was significantly different from Brazilian and French meat. Comparing the levels of Na shows that in the earlier study Swiss samples had been already higher in Na content than that in Brazilian and French samples. This is confirmed by the present study. Levels in general were now higher. $\mathrm{Rb}$ was found useful to separate Brazilian and German samples in the first study, and now Brazilian samples could be separated from all other origins by their higher level of RB. French samples differed from other origins in $\mathrm{Tl}$ in the first study and now $\mathrm{Tl}$ was useful to distinguish French and German from other origins. This is consistent with the observation that in the first study German samples had been numerically higher in $\mathrm{Tl}$ than all other origins except France. As the discrimination power depends on the number of samples and the first study included fewer samples, differences in element levels of certain origins were now significant which were not yet significant in the first study. However, overall tendencies found in the first study were widely recovered again, sometimes with better discriminating abilities. Due to methodological limitations occurring in the first study, $\mathrm{Se}$ and $\mathrm{Sr}$ could not be determined with sufficient accuracy, which is why their potential to separate the origins was not elucidated. 
Table 1 Element concentrations referring to the country of origin of poultry breasts

\begin{tabular}{|c|c|c|c|c|c|c|c|c|c|c|c|}
\hline \multirow[b]{2}{*}{${ }^{75} \mathrm{As}(\mu \mathrm{g} / \mathrm{kg})$} & \multirow{2}{*}{$\frac{p^{\mathrm{a}}}{* *}$} & \multicolumn{2}{|c|}{ Brazil $(n=10)$} & \multicolumn{2}{|c|}{ France $(n=11)$} & \multicolumn{2}{|c|}{ Germany $(n=12)$} & \multicolumn{2}{|c|}{ Hungary $(n=10)$} & \multicolumn{2}{|c|}{ Switzerland $(n=13)$} \\
\hline & & $5.81 \mathrm{ab}$ & 1.96 & $5.11 \mathrm{~b}$ & 1.85 & $4.62 \mathrm{~b}$ & 1.09 & $10.68 \mathrm{a}$ & 8.99 & $6.18 \mathrm{ab}$ & 2.12 \\
\hline${ }^{23} \mathrm{Na}(\mathrm{mg} / \mathrm{kg})$ & $* *$ & $125 \mathrm{ab}$ & 21 & $125 \mathrm{~b}$ & 23 & $145 \mathrm{ab}$ & 18 & $133 \mathrm{ab}$ & 23 & $154 \mathrm{a}$ & 28 \\
\hline${ }^{85} \mathrm{Rb}(\mathrm{mg} / \mathrm{kg})$ & $* * *$ & $12.2 \mathrm{~b}$ & 2.4 & $8.0 \mathrm{a}$ & 2.5 & $7.3 \mathrm{a}$ & 1.2 & $8.8 \mathrm{a}$ & 1.5 & $7.6 \mathrm{a}$ & 2.1 \\
\hline${ }^{77} \mathrm{Se}(\mu \mathrm{g} / \mathrm{kg})$ & $* * *$ & $109 \mathrm{~b}$ & 34 & $130 \mathrm{ab}$ & 22 & $121 \mathrm{~b}$ & 20 & $158 \mathrm{a}$ & 31 & $160 \mathrm{a}$ & 30 \\
\hline${ }^{88} \mathrm{Sr}(\mu \mathrm{g} / \mathrm{kg})$ & $* * *$ & $60.1 \mathrm{c}$ & 33.7 & $20.5 \mathrm{a}$ & 5.3 & $45.1 \mathrm{bc}$ & 20.7 & $31.7 \mathrm{ab}$ & 14.1 & $23.1 \mathrm{ab}$ & 10.6 \\
\hline${ }^{205} \mathrm{Tl}(\mu \mathrm{g} / \mathrm{kg})$ & $* * *$ & $1.31 \mathrm{a}$ & 0.48 & $4.16 \mathrm{~b}$ & 3.87 & $4.77 \mathrm{~b}$ & 1.42 & $1.51 \mathrm{a}$ & 0.97 & $1.39 \mathrm{a}$ & 1.02 \\
\hline
\end{tabular}

Only elements with significant country effects included; means from different countries of origin without common letter are significantly different $(p<0.05)$. Note: the discrimination power among countries depends on numbers of observation. The values are means and standard deviations

${ }^{a}$ Effect of country of origin: $* * p<0.01, * * * p<0.001$

Of all elements, except As, values in the earlier and the present study fit together. The reasons why the As values were lower now (6 vs. $32 \mu \mathrm{g} / \mathrm{kg}$ on average across countries) are not clear.

Stepwise backward LDA (multivariate statistical analysis) of the elements analyzed in poultry meat allowed to establish a jackknifed classification matrix including the elements As, B, Ca, Cr, Ga, Li, Mo, Na, Ni, Rb, Se, Sr, Tl, and $\mathrm{V}$. The mean correct classification rate of all samples was $77 \%$ (Table 2). Only Brazilian samples could be grouped at $100 \%$. All other origins could not be determined completely correct and, within each origin, misclassifications of other origins were found. These rates are not as promising as the first ones [6] where Brazil, Germany, Thailand, and Hungary were entirely correctly classified. However, as substantially more samples were analyzed this time, these sample sets probably better represented the with-in country variability.

Discrimination of dried beef origins by elements and element signature

Fifty-one out of 65 elements/isotopes analyzed (all except ${ }^{9} \mathrm{Be},{ }^{52} \mathrm{Cr},{ }^{60} \mathrm{Ni},{ }^{78} \mathrm{Se},{ }^{109} \mathrm{Ag},{ }^{113} \mathrm{Cd},{ }^{128} \mathrm{Te},{ }^{137} \mathrm{Ba},{ }^{151} \mathrm{Eu}$, ${ }^{153} \mathrm{Eu},{ }^{159} \mathrm{~Tb},{ }^{169} \mathrm{Tm},{ }^{175} \mathrm{Lu}$, and ${ }^{232} \mathrm{Th}$ ) ranged beyond the detection level in dried beef. Group differences $(p<0.05)$ were found for $\mathrm{As}, \mathrm{B}, \mathrm{Ba}, \mathrm{Ca}, \mathrm{Cd}, \mathrm{Cu}, \mathrm{Dy}, \mathrm{Er}, \mathrm{Fe}, \mathrm{Li}, \mathrm{Mn}$, $\mathrm{Pd}, \mathrm{Rb}, \mathrm{Se}, \mathrm{Sr}, \mathrm{Te}, \mathrm{Tl}, \mathrm{U}, \mathrm{V}$, and Y (Table 3). Among the elements not considered due to analytical constraints in the preliminary investigation [6], Se was found to differ between samples of Swiss raw meat origin and USA, where the US samples had Se concentrations twice as high as the Swiss samples similar to earlier reports [2, 13]. Austrian samples could be separated from all other origins, because their $\mathrm{Sr}$ level was found to be more than two times higher compared to the others, which is consistent with earlier findings [6]. There were overall group differences $(p<0.05)$ in $\mathrm{Y}$ concentration of the beef, but the Bonferroni-adjusted pairwise comparison did not specify any distinct group separations. The elements $\mathrm{B}, \mathrm{Ca}, \mathrm{Cd}, \mathrm{Cu}, \mathrm{Dy}$, $\mathrm{Li}, \mathrm{Pd}, \mathrm{Rb}, \mathrm{Sr}, \mathrm{Te}, \mathrm{Tl}$, and $\mathrm{V}$ had already been found useful to separate dried beef by raw meat origin and place of processing as single grouping parameters in the preliminary study [6]. The group differentiation found in the earlier study [6] for the element $\mathrm{Sr}$ was now completely confirmed. The discrimination power of the elements Li (US samples distinguished from Australian samples and samples of Brazilian raw meat), $\mathrm{Rb}$ (raw meat origins of Swiss samples separated, Canadian and Swiss raw meat differentiated), Te (differentiation between USA and Australia), and V (US separated, due to higher $\mathrm{V}$ levels) found earlier was partly confirmed. Some more elements (As, Ba, Er, Fe, Mn, and $\mathrm{U})$, which had not been significant in [6], now showed potential to distinguish between certain origins. This list included several elements, which are probably of both naturally or human-induced characteristic for distinct
Table 2 Jackknifed classification matrix of poultry breast meat

Figures represent sample numbers

\begin{tabular}{lcccccc}
\hline Actual origin & \multicolumn{2}{l}{ Predicted origin } & & & \\
\cline { 2 - 6 } & Brazil & France & Germany & Hungary & Switzerland & \% Correct \\
\hline Brazil & 10 & 0 & 0 & 0 & 0 & 100 \\
France & 0 & 7 & 3 & 1 & 0 & 64 \\
Germany & 0 & 1 & 10 & 0 & 1 & 83 \\
Hungary & 1 & 2 & 0 & 6 & 1 & 60 \\
Switzerland & 1 & 1 & 0 & 1 & 10 & 77 \\
Overall & 12 & 11 & 13 & 8 & 12 & 77 \\
\hline
\end{tabular}


Table 3 Element concentrations referring to the country of origin and site of processing of dried beef

\begin{tabular}{|c|c|c|c|c|c|c|c|c|c|c|c|c|c|c|c|}
\hline \multirow[b]{2}{*}{${ }^{75} \mathrm{As}(\mu \mathrm{g} / \mathrm{kg})$} & \multirow{2}{*}{$\frac{P^{\mathrm{a}}}{* *}$} & \multicolumn{2}{|c|}{$\mathrm{AU}-\mathrm{AU}(n=4)$} & \multicolumn{2}{|c|}{$\mathrm{BR}-\mathrm{AT}(n=4)$} & \multicolumn{2}{|c|}{ BR-GR $(n=12)$} & \multicolumn{2}{|c|}{$\mathrm{CH}-\mathrm{GR}(n=12)$} & \multicolumn{2}{|c|}{$\mathrm{CH}-\mathrm{VS}(n=12)$} & \multicolumn{2}{|c|}{$\mathrm{CN}-\mathrm{CN}(n=6)$} & \multicolumn{2}{|c|}{ US-US $(n=3)$} \\
\hline & & $136 \mathrm{~b}$ & 18 & $196 a b$ & 30 & $142 \mathrm{~b}$ & 40 & $146 \mathrm{~b}$ & 31 & $147 \mathrm{~b}$ & 35 & $141 \mathrm{~b}$ & 39 & $222 \mathrm{a}$ & 30 \\
\hline${ }^{10} \mathrm{~B}(\mu \mathrm{g} / \mathrm{kg})$ & $* * *$ & $186 \mathrm{c}$ & 64 & $202 \mathrm{bc}$ & 80 & $199 \mathrm{c}$ & 81 & $374 \mathrm{a}$ & 86 & $291 \mathrm{abc}$ & 80 & $243 \mathrm{bc}$ & 72 & $389 a b$ & 290 \\
\hline${ }^{137} \mathrm{Ba}(\mu \mathrm{g} / \mathrm{kg})$ & $* * *$ & $27.2 \mathrm{bc}$ & 4.7 & $25.8 \mathrm{bc}$ & 8.4 & $22.6 \mathrm{c}$ & 11.6 & $23.1 \mathrm{c}$ & 8.7 & $41.3 \mathrm{ab}$ & 18.4 & $54.2 \mathrm{a}$ & 7.0 & $51.2 \mathrm{ab}$ & 8.1 \\
\hline${ }^{42} \mathrm{Ca}(\mathrm{mg} / \mathrm{kg})$ & $* * *$ & $76 \mathrm{bcd}$ & 10 & $123 \mathrm{ab}$ & 30 & $73 \mathrm{~d}$ & 19 & $77 \mathrm{~cd}$ & 22 & $104 \mathrm{ac}$ & 35 & $120 \mathrm{ab}$ & 8 & $144 \mathrm{a}$ & 10 \\
\hline${ }^{11} \mathrm{Cd}(\mu \mathrm{g} / \mathrm{kg})$ & $* *$ & $0.97 \mathrm{ab}$ & 0.12 & $1.17 \mathrm{ab}$ & 0.41 & $0.78 \mathrm{~b}$ & 0.34 & $1.13 \mathrm{ab}$ & 0.22 & $1.18 \mathrm{ab}$ & 0.38 & $1.25 \mathrm{ab}$ & 0.43 & $1.55 \mathrm{a}$ & 0.28 \\
\hline${ }^{63} \mathrm{Cu}(\mathrm{mg} / \mathrm{kg})$ & $* *$ & $2.42 \mathrm{ab}$ & 0.30 & $2.47 \mathrm{ab}$ & 0.69 & $2.04 \mathrm{~b}$ & 0.34 & $2.16 \mathrm{~b}$ & 0.40 & $2.03 \mathrm{~b}$ & 0.33 & $2.00 \mathrm{~b}$ & 0.40 & $3.09 \mathrm{a}$ & 0.35 \\
\hline${ }^{161}$ Dy $(\mu \mathrm{g} / \mathrm{kg})$ & $*$ & $0.050 \mathrm{~b}$ & 0.008 & $0.085 \mathrm{ab}$ & 0.019 & $0.085 \mathrm{a}$ & 0.023 & $0.074 \mathrm{ab}$ & 0.015 & $0.079 \mathrm{ab}$ & 0.021 & $0.070 \mathrm{ab}$ & 0.015 & $0.050 \mathrm{ab}$ & 0.017 \\
\hline${ }^{167} \operatorname{Er}(\mu \mathrm{g} / \mathrm{kg})$ & $* * *$ & $0.26 \mathrm{bc}$ & 0.06 & $0.42 \mathrm{ab}$ & 0.14 & $0.27 \mathrm{c}$ & 0.08 & $0.26 \mathrm{c}$ & 0.07 & $0.22 \mathrm{c}$ & 0.05 & $0.22 \mathrm{c}$ & 0.09 & $0.48 \mathrm{a}$ & 0.03 \\
\hline${ }^{57} \mathrm{Fe}(\mathrm{mg} / \mathrm{kg})$ & $* * *$ & $43.4 \mathrm{ab}$ & 9.3 & $19.9 \mathrm{c}$ & 4.0 & $35.2 \mathrm{~cd}$ & 11.3 & $54.9 \mathrm{a}$ & 11.7 & $43.0 \mathrm{ab}$ & 9.7 & $33.0 \mathrm{bc}$ & 5.7 & $40.0 \mathrm{abc}$ & 4.8 \\
\hline${ }^{7} \mathrm{Li}(\mu \mathrm{g} / \mathrm{kg})$ & $* * *$ & $9.9 \mathrm{~d}$ & 2.8 & $27.1 \mathrm{c}$ & 11.0 & $9.9 \mathrm{~d}$ & 2.3 & $15.6 \mathrm{bcd}$ & 8.3 & $13.0 \mathrm{bd}$ & 2.5 & $23.3 \mathrm{bc}$ & 9.7 & $55.8 \mathrm{a}$ & 8.5 \\
\hline${ }^{55} \mathrm{Mn}(\mu \mathrm{g} / \mathrm{kg})$ & $* * *$ & $243 \mathrm{bc}$ & 61 & $280 \mathrm{bc}$ & 97 & $193 \mathrm{c}$ & 87 & $215 b c$ & 70 & $227 \mathrm{bc}$ & 65 & $342 \mathrm{~b}$ & 164 & $1005 \mathrm{a}$ & 59 \\
\hline${ }^{104} \mathrm{Pd}(\mu \mathrm{g} / \mathrm{kg})$ & $* * *$ & $9.4 \mathrm{~b}$ & 1.0 & $10.0 \mathrm{a}$ & 5.0 & $7.9 \mathrm{~b}$ & 8.1 & $4.3 \mathrm{~b}$ & 2.0 & $4.2 \mathrm{~b}$ & 1.5 & $6.2 \mathrm{~b}$ & 0.8 & $5.0 \mathrm{~b}$ & 0.4 \\
\hline${ }^{85} \mathrm{Rb}(\mathrm{mg} / \mathrm{kg})$ & $* * *$ & $7.5 \mathrm{ac}$ & 1.2 & $16.5 \mathrm{bc}$ & 3.3 & $16.5 \mathrm{ab}$ & 5.3 & $4.9 \mathrm{c}$ & 1.6 & $6.5 \mathrm{c}$ & 3.4 & $22.5 \mathrm{~b}$ & 18.8 & $7.8 \mathrm{bc}$ & 0.8 \\
\hline${ }^{77} \mathrm{Se}(\mu \mathrm{g} / \mathrm{kg})$ & $* *$ & $307 a b$ & 164 & $400 \mathrm{ab}$ & 97 & $282 \mathrm{ab}$ & 209 & $216 \mathrm{~b}$ & 62 & $225 \mathrm{~b}$ & 83 & $265 \mathrm{ab}$ & 146 & $514 \mathrm{a}$ & 63 \\
\hline${ }^{88} \mathrm{Sr}(\mu \mathrm{g} / \mathrm{kg})$ & $* * *$ & $406 \mathrm{~b}$ & 45 & $1018 \mathrm{a}$ & 356 & $355 \mathrm{~b}$ & 434 & $165 \mathrm{~b}$ & 102 & $137 \mathrm{~b}$ & 50 & $262 \mathrm{~b}$ & 39 & $225 \mathrm{~b}$ & 18 \\
\hline${ }^{126} \mathrm{Te}(\mu \mathrm{g} / \mathrm{kg})$ & $* *$ & $10.7 \mathrm{~b}$ & 1.6 & $13.3 \mathrm{ab}$ & 1.9 & $12.0 \mathrm{~b}$ & 1.9 & $11.8 \mathrm{~b}$ & 2.2 & $10.7 \mathrm{~b}$ & 0.7 & $10.9 \mathrm{~b}$ & 2.4 & $16.8 \mathrm{a}$ & 2.5 \\
\hline${ }^{203} \mathrm{Tl}(\mu \mathrm{g} / \mathrm{kg})$ & $* * *$ & $0.22 \mathrm{~b}$ & 0.04 & $0.22 \mathrm{~b}$ & 0.11 & $0.30 \mathrm{~b}$ & 0.11 & $0.20 \mathrm{~b}$ & 0.06 & $0.35 \mathrm{~b}$ & 0.13 & $1.83 \mathrm{a}$ & 2.00 & $0.14 \mathrm{~b}$ & 0.02 \\
\hline${ }^{238} \mathrm{U}(\mu \mathrm{g} / \mathrm{kg})$ & $* * *$ & $0.16 \mathrm{~b}$ & 0.03 & $0.56 \mathrm{a}$ & 0.29 & $0.18 \mathrm{~b}$ & 0.11 & $0.23 \mathrm{~b}$ & 0.12 & $0.17 \mathrm{~b}$ & 0.09 & $0.09 \mathrm{~b}$ & 0.04 & $0.20 \mathrm{~b}$ & 0.04 \\
\hline${ }^{51} \mathrm{~V}(\mu \mathrm{g} / \mathrm{kg})$ & $* * *$ & $0.41 \mathrm{~b}$ & 0.15 & $0.90 \mathrm{~b}$ & 0.35 & $1.03 \mathrm{~b}$ & 0.68 & $0.62 \mathrm{~b}$ & 0.19 & $0.93 \mathrm{~b}$ & 0.50 & $0.85 \mathrm{~b}$ & 0.34 & $3.97 \mathrm{a}$ & 1.14 \\
\hline
\end{tabular}

Only elements with significant country effects included; means from different countries of origin without common letter are significantly different $(p<0.05)$. Note: the discrimination power among countries depends on numbers of observation. The values are means and standard deviations. The first acronym denominates country of origin, the second the site of processing

$A U$ Australia; AT Austria; CN Canada; BR Brazil; GR Canton of Grisons, Switzerland; US United States of America; VS Canton of Valais, Switzerland

${ }^{\text {a }}$ Effect of country of origin: $* p<0.05, * * p<0.01, * * * p<0.001$

geographic regions as outlined in the Introduction. The levels of the elements $\mathrm{As}, \mathrm{Ba}, \mathrm{Ca}, \mathrm{Cd}, \mathrm{Fe}, \mathrm{Li}, \mathrm{Mn}, \mathrm{Rb}$, and $\mathrm{Sr}$ were similar to those found earlier, while $\mathrm{Dy}, \mathrm{Pd}, \mathrm{Te}, \mathrm{Tl}$, and $U$ differed in levels maybe because of the minor changes made in analysis. For the remaining elements, reasons for different concentrations are not clear.

Multivariate statistical analysis using LDA for dried beef showed that a combination of the elements $\mathrm{Ba}, \mathrm{Ca}, \mathrm{Cd}$, Dy, $\mathrm{Fe}, \mathrm{Ga}, \mathrm{Li}, \mathrm{Mg}, \mathrm{Mn}, \mathrm{Pd}, \mathrm{Rb}, \mathrm{Sr}, \mathrm{Tl}, \mathrm{U}$, and $\mathrm{V}$ allowed to establish a classification matrix with a mean overall classification rate of $79 \%$ (Table 4). These were mostly, but not completely, the same as those showing significant group differences and, like in poultry meat, included many regionspecific elements. Samples from Australia and USA were all correctly assigned. Also samples of Brazilian and Swiss raw meat origin were entirely classified as such, but there were misclassifications among the places of processing (Austria and Switzerland for Brazilian raw meat; Grisons and Valais for Swiss raw meat). No misclassification was detected between the groups based on Brazilian or Swiss raw meat processed in the Swiss Canton of Grisons showing that different raw meat origins could be differentiated even when processed in the same place. No samples of other origin were misclassified as Canadian and US samples. Furthermore, no samples of non-Swiss raw meat origin were misclassified within the group comprising Swiss beef processed in Grisons. This means that all samples predicted as coming from either USA or Canada really originated from there.

Evaluation of the method by combining the data of the preliminary study and the current study

The Wilcoxon-Mann-Whitney tests on the element concentrations of reference materials yielded significant differences between the two sample sets for the elements ${ }^{45} \mathrm{Sc}$, ${ }^{53} \mathrm{Cr},{ }^{67} \mathrm{Zn},{ }^{68} \mathrm{Zn},{ }^{104} \mathrm{Pd},{ }^{128} \mathrm{Te},{ }^{141} \mathrm{Pr},{ }^{151} \mathrm{Eu},{ }^{153} \mathrm{Eu},{ }^{161} \mathrm{Dy}$, ${ }^{163} \mathrm{Dy},{ }^{169} \mathrm{Tm},{ }^{171} \mathrm{Yb},{ }^{172} \mathrm{Yb},{ }^{203} \mathrm{Tl},{ }^{209} \mathrm{Bi}$, and ${ }^{238} \mathrm{U}$. These elements are uncommon and occur only in low concentrations, and were excluded from further statistical analysis. Reasons for these differences might again be found in the minor changes in ICP-MS analysis made and in unavoidable trends all day routine.

For poultry, it was not possible by cross-validation to classify the samples correctly according to their origin (Table 5), based on the elements ${ }^{23} \mathrm{Na},{ }^{44} \mathrm{Ca},{ }^{51} \mathrm{~V},{ }^{75} \mathrm{As}$, 
Table 4 Jackknifed classification matrix of dried beef

\begin{tabular}{|c|c|c|c|c|c|c|c|c|}
\hline \multirow[t]{2}{*}{ Actual origin } & \multicolumn{8}{|c|}{ Predicted origin } \\
\hline & $\mathrm{AU}-\mathrm{AU}$ & $\mathrm{BR}-\mathrm{AT}$ & BR-GR & $\mathrm{CH}-\mathrm{GR}$ & $\mathrm{CH}-\mathrm{VS}$ & $\mathrm{CN}-\mathrm{CN}$ & US-US & $\%$ Correct \\
\hline $\mathrm{AU}-\mathrm{AU}$ & 4 & 0 & 0 & 0 & 0 & 0 & 0 & 100 \\
\hline BR-AT & 0 & 3 & 1 & 0 & 0 & 0 & 0 & 75 \\
\hline BR-GR & 0 & 2 & 10 & 0 & 0 & 0 & 0 & 83 \\
\hline $\mathrm{CH}-\mathrm{GR}$ & 1 & 0 & 0 & 9 & 2 & 0 & 0 & 75 \\
\hline $\mathrm{CH}-\mathrm{VS}$ & 0 & 0 & 0 & 3 & 9 & 0 & 0 & 75 \\
\hline $\mathrm{CN}-\mathrm{CN}$ & 0 & 0 & 1 & 0 & 1 & 4 & 0 & 67 \\
\hline US-US & 0 & 0 & 0 & 0 & 0 & 0 & 3 & 100 \\
\hline Overall & 5 & 5 & 12 & 12 & 12 & 4 & 3 & 79 \\
\hline
\end{tabular}

AU Australia; AT Austria; $C H$ Switzerland; CN Canada; BR Brazil; GR Canton of Grisons, Switzerland; US United States of America; VS Canton of Valais, Switzerland

${ }^{a}$ Figures represent sample numbers. The first acronym denominates country of origin, the second the site of processing

Table 5 Jackknifed classification and validation matrix of poultry breast meat sample set 1 and $2^{a}$ a Figures represent sample numbers. Sample set 1 data are published in [6]

\begin{tabular}{lcccccc}
\hline Actual origin & \multicolumn{2}{l}{ Predicted origin } & & & \\
\cline { 2 - 7 } & Brazil & France & Germany & Hungary & Switzerland & \% Correct \\
\hline Cross-validation (jackknife) & & & & & \\
Brazil & 13 & 0 & 0 & 1 & 0 & 93 \\
France & 0 & 5 & 3 & 3 & 2 & 38 \\
Germany & 0 & 1 & 13 & 0 & 1 & 87 \\
Hungary & 0 & 1 & 0 & 11 & 4 & 69 \\
Switzerland & 2 & 0 & 2 & 1 & 15 & 75 \\
Overall & 15 & 7 & 18 & 16 & 22 & 73 \\
Validation & & & & & & 100 \\
Brazil & 4 & 0 & 0 & 0 & 0 & 100 \\
France & 0 & 2 & 0 & 0 & 0 & 0 \\
Germany & 0 & 3 & 0 & 0 & 0 & 83 \\
Hungary & 0 & 1 & 0 & 5 & 0 & 0 \\
Switzerland & 1 & 2 & 0 & 4 & 0 & 50 \\
Overall & 5 & 8 & 0 & 9 & 0 & \\
\hline
\end{tabular}

${ }^{85} \mathrm{Rb},{ }^{88} \mathrm{Sr},{ }^{111} \mathrm{Cd},{ }^{155} \mathrm{Gd}$, and ${ }^{205} \mathrm{Tl}$. No origin was classified correctly at $100 \%$ and, in each group of origin, samples of other origins were misclassified. Validation was based on the elements ${ }^{23} \mathrm{Na},{ }^{44} \mathrm{Ca},{ }^{51} \mathrm{~V},{ }^{75} \mathrm{As},{ }^{85} \mathrm{Rb},{ }^{86} \mathrm{Sr},{ }^{88} \mathrm{Sr},{ }^{95} \mathrm{Mo}$, ${ }^{142} \mathrm{Nd}$, and ${ }^{205} \mathrm{Tl}$. Samples from Brazil and France were classified completely correctly, but samples of other origins were misclassified into these origins as well. No samples (neither correctly nor incorrectly) were identified as being German and Swiss. German samples were completely misclassified as French ones, and Swiss samples were mostly identified as being Hungarian. Reasons for these findings are probably the absence of clear differences in element content between these origins. This shows that it is possible to determine whether Brazilian and French samples really originate from the corresponding countries, but a clear determination of samples from unknown origins is obviously difficult according to the high rate of misclassifications.

From the combination of the two dried beef samples sets, LDA selected the elements ${ }^{10} \mathrm{~B},{ }^{63} \mathrm{Cu},{ }^{69} \mathrm{Ga},{ }^{7} \mathrm{Li},{ }^{95} \mathrm{Mo}$, ${ }^{85} \mathrm{Rb},{ }^{82} \mathrm{Se},{ }^{86} \mathrm{Sr},{ }^{88} \mathrm{Sr}$, and ${ }^{51} \mathrm{~V}$ as being suitable to group $70 \%$ of all samples correctly in a jackknifed classification matrix (Table 6). Although no origin could be classified at $100 \%$, there were no misclassifications into US samples, meaning that unknown samples predicted as being from USA really came from there. Predicting the group of samples from the first study by using the discriminant model of the second dataset (validation) was based on the elements ${ }^{10} \mathrm{~B},{ }^{42} \mathrm{Ca},{ }^{63} \mathrm{Cu},{ }^{7} \mathrm{Li},{ }^{85} \mathrm{Rb},{ }^{82} \mathrm{Se},{ }^{86} \mathrm{Sr}$, and ${ }^{88} \mathrm{Sr}$. Samples processed in Austria using Brazilian meat as well as Canadian samples were predicted completely correctly. Within the raw beef coming from Australia, Brazil (processed in 
Table 6 Jackknifed classification and validation matrix of dried beef sample set 1 and 2

\begin{tabular}{|c|c|c|c|c|c|c|c|c|}
\hline \multirow[t]{2}{*}{ Actual origin } & \multicolumn{8}{|c|}{ Predicted origin } \\
\hline & $\mathrm{AU}-\mathrm{AU}$ & $\mathrm{BR}-\mathrm{AT}$ & BR-GR & $\mathrm{CH}-\mathrm{GR}$ & $\mathrm{CH}-\mathrm{VS}$ & $\mathrm{CN}-\mathrm{CN}$ & US-US & $\%$ Correct \\
\hline \multicolumn{9}{|c|}{ Cross-validation (jackknife) } \\
\hline $\mathrm{AU}-\mathrm{AU}$ & 6 & 0 & 0 & 2 & 0 & 0 & 0 & 75 \\
\hline $\mathrm{BR}-\mathrm{AT}$ & 2 & 4 & 0 & 0 & 0 & 0 & 0 & 67 \\
\hline BR-GR & 0 & 1 & 14 & 1 & 0 & 0 & 0 & 88 \\
\hline $\mathrm{CH}-\mathrm{GR}$ & 0 & 0 & 3 & 10 & 2 & 1 & 0 & 63 \\
\hline $\mathrm{CH}-\mathrm{VS}$ & 0 & 0 & 0 & 5 & 10 & 0 & 0 & 67 \\
\hline $\mathrm{CN}-\mathrm{CN}$ & 0 & 0 & 1 & 2 & 1 & 4 & 0 & 50 \\
\hline US-US & 1 & 0 & 0 & 0 & 0 & 0 & 4 & 80 \\
\hline Overall & 9 & 5 & 18 & 20 & 13 & 5 & 4 & 70 \\
\hline \multicolumn{9}{|l|}{ Validation } \\
\hline AU-AU & 1 & 0 & 0 & 3 & 0 & 0 & 0 & 25 \\
\hline $\mathrm{BR}-\mathrm{AT}$ & 0 & 2 & 0 & 0 & 0 & 0 & 0 & 100 \\
\hline BR-GR & 0 & 0 & 2 & 2 & 0 & 0 & 0 & 50 \\
\hline $\mathrm{CH}-\mathrm{GR}$ & 0 & 0 & 0 & 3 & 1 & 0 & 0 & 75 \\
\hline $\mathrm{CH}-\mathrm{VS}$ & 0 & 0 & 0 & 3 & 0 & 0 & 0 & 0 \\
\hline $\mathrm{CN}-\mathrm{CN}$ & 0 & 0 & 0 & 0 & 0 & 2 & 0 & 100 \\
\hline US-US & 0 & 0 & 0 & 2 & 0 & 0 & 0 & 0 \\
\hline Overall & 1 & 2 & 2 & 13 & 1 & 2 & 0 & 48 \\
\hline
\end{tabular}

AU Australia; AT Austria; CN Canada; BR Brazil; GR Canton of Grisons, Switzerland; US United States of America; VS Canton of Valais, Switzerland

${ }^{a}$ Figures represent sample numbers. Sample set 1 data are published in [6]. The first acronym denominates country of origin, the second the site of processing

Austria or Grisons), and Canada no samples of other origins were misclassified, meaning that samples identified as such really originated from there. This was also the case for the USA, but as no US samples were classified correctly this has no explanatory power concerning the classification. For unknown reasons both US samples were determined as being processed in Switzerland out of Swiss raw meat. No misclassifications occurred with samples of Brazilian raw meat origin processed in either Austria or Grisons.

A special emphasis of the study was given to testing several dried beef sources from processing in Switzerland but done so at different places and from different raw beef origins. Generally, all samples processed in Switzerland from different raw meat origins were also grouped by the present analysis into one of the Swiss groups. All samples processed in Valais were predicted to be processed in Grisons from Swiss raw meat and one of the samples processed in Grisons was predicted as to originate from Valais. However, at least all Swiss raw meat samples were identified of being Swiss, although it was not possible to differentiate between the two Swiss cantons. It was also impossible to separate samples processed in Grisons of different raw meat origin, as half of the samples of Brazilian raw meat origin were misclassified as being made from Swiss raw meat. Although different raw meat origins are treated separately during processing, receipts, and ingredients (e.g. salt, herbs) stay mostly the same for each producer, and these ingredients also contribute to the element signature of the dried beef, which might explain the impossibility to differ between Brazilian and Swiss raw meat.

\section{Conclusion}

The present study on an extended sample size basically confirmed the usefulness of individual element and multielement profiles for geographic authentication of poultry meat and dried beef which had been expected from the preliminary study [6]. Widely the same elements/isotopes contributed for differentiation. It seems basically possible to set up a statistical prediction system from a sufficiently large sample size to be used later with other samples. For poultry it was possible to differ between certain origins using the elements ${ }^{75} \mathrm{As},{ }^{23} \mathrm{Na},{ }^{85} \mathrm{Rb},{ }^{77} \mathrm{Se},{ }^{88} \mathrm{Sr}$, and ${ }^{205} \mathrm{Tl}$, but it was almost impossible to set reliable threshold values to be applied for individual samples, a prerequisite for official use. A combination of several elements did not allow classifying origins entirely correctly. For dried beef, determination of the place of processing was feasible using multivariate analysis. Also the prediction of the origins of the 
samples of the first study, using the discriminant models developed using the second sample set, was possible with some limitations. The results indicate that it is possible to determine at least whether samples of Swiss origin are really coming from Switzerland. Element analysis is a helpful tool in determining the geographic origin of raw and processed meat, but the accuracy could be improved by combining this approach with further techniques.

Acknowledgment We are grateful to Bell AG, Bischofberger AG, Fredag, Micarna SA and Ernst Kneuss Geflügel AG who provided the poultry samples as well as to Albert Spiess AG, Cher-Mignon SA, Fleischtrocknerei Churwalden AG, Gabriel Fleury SA, Natura Bündner Fleischtrocknerei, and Surselva Fleischwaren AG, which provided the European and Australian dried beef samples. We also like to thank the Swiss embassies of USA and Canada who assisted in organizing the American and Canadian dried beef samples, the Swiss Federal Office of Public Health for its financial support and Werner Luginbühl from Chemstat, Berne, for the advice in statistical analysis and for partly reviewing the manuscript.

\section{References}

1. Anke M, Angelow L (1995) Fresenius J Anal Chem 352:236-239

2. Hintze KJ, Lardy GP, Marchello MJ, Finley JW (2001) J Agric Food Chem 49:1062-1067

3. Gremaud G, Karlen S, Hulliger K (2002) Mitt Lebensm Hyg 93:481-501

4. Bruce SL, Noller BN, Grigg AH, Mullen BF, Mulligan DR, Ritchie PJ, Currey N, Ng JC (2003) Toxicol Lett 137:23-34

5. Franke BM, Gremaud G, Hadorn R, Kreuzer M (2005) Eur Food Res Technol 221:493-503

6. Franke BM, Haldimann M, Reimann J, Baumer B, Gremaud G, Bosset JO, Hadorn R, Kreuzer M (2007) Eur Food Res Technol 225:501-509

7. Anonymous (2001) Arsenic in drinking water, http://www.who. int/mediacentre/factsheets/fs210/en/index.html. Accessed on 13 July 2007

8. Anonymous (2005) Environmental Health Criteria 18: Arsenic, http://www.inchem.org/documents/ehc/ehc/ehc018.htm\#SubSectionNumber:1.1.2. Accessed on 13 July 2007

9. WHO (2005) Arsenic Contamination in Ground Water Affecting Some Countries in the South-East Asia Region, http://www.searo. who.int/meeting/rc/rc54/54_8.htm. Accessed on 18 April 2007
10. Kim KW, Thornton I (1993) Environ Geochem Health 15:119133

11. Baldini M, Stacchini $\mathrm{P}$, Cubadda F, Miniero R, Parodi $\mathrm{P}$, Facelli $\mathrm{P}$ (2000) Food Addit Contam 17:679-687

12. Jevsnik M, Doganoc DZ (2003) J Food Prot 66:686-690

13. Haldimann M, Dufossé K, Mompart A, Zimmerli B (1999) Mitt Lebensm Hyg 90:241-281

14. Ruz M, Codoceo J, Hurtado S, Munoz L, Gras N (1995) J Trace Elem Med Biol 9:156-159

15. Leiber $F$ (2005) Causes and extent of variation in yield, nutritional quality and cheese-making properties of milk by high altitude grazing of dairy cows. Doctoral Thesis, No. 15735, ETH Zurich, Zurich, Switzerland

16. Tremel A, Masson P, Sterckeman T, Baize D, Mench M (1997) Environ Pollut 95:293-302

17. Xiao T, Guha J, Boyle D (2004) Geochem 4:243-252

18. Eschnauer H, Gemmer-Colos V, Neeb R (1984) Z Lebensm Unters Forsch 178:453-460

19. Bruce SL, Noller BN, Grigg AH, Mullen BF, Mulligan DR, Ritchie PJ, Currey N, Ng JC (2003) Toxicol Lett 137:23-34

20. Horvat M, Nolde N, Fajon V, Jereb V, Logar M, Lojen S, Jacimovic R, Falnogy I, Liya Q, Faganeli J, Drobne D (2003) Sci Total Environ 304:231-256

21. Chessa G, Calaresu G, Ledda G, Testa MC, Orrù A (2000) Lead, zinc and cadmium in biological tissues of sheep bred in a polluted area. In: Markert B, Friese K (eds) Trace elements-their distribution and effects in the environment. Elsevier, Amsterdam, pp 497 483

22. National Research Council (1994) Nutrient requirement of poultry. National Academy Press, Washington DC

23. Ausschuss für Bedarfsforschung der Gesellschaft für Ernährungsphysiologie (1999) Empfehlungen zur Energie- und Nährstoffversorgung von Legehennen und Masthühnern (Broiler). DLG, Frankfurt/Main

24. National Research Council (2000) Nutrient requirement of beef cattle. National Academy Press, Washington DC

25. Anonymous (2005) Mineralfutter für Rinder, http://www.gundelgailroth.de/futtermittel/mineralfutter-rinder.htm. Accessed on 13 July 2007

26. Eurola M, Ekholm P, and Venäläinen E-J (2005) Selenium supplemented fertilization - effects on the selenium content of foods and the selenium intake in Finland, http://www.lbhi.is/landbunadur/ wglbhi.nsf/Attachment/LBHI-rit-3/\$file/LBHI-rit-3.pdf. Accessed on 13 July 2007

27. Hintze KJ, Lardy GP, Marchello MJ, Finley JW (2002) J Agric Food Chem 50:3938-3942

28. Sager M (2005) Ernährung/Nutrition 29:199-206 